\title{
Freedom, so close but yet so far: The impact of the ongoing confrontation with freedom on the perceived severity of punishment
}

\author{
Helene De Vos \\ Leuven Institute of Criminology, KU Leuven, Belgium; Helene.devos@ kuleuven.be (corr. author) \\ Elli Gilbert \\ Leuven Institute of Criminology, KU Leuven, Belgium
}

\begin{abstract}
The severity of a particular sentence is often assumed to be reflected by its degree of libertyrestriction: a five-year prison sentence is considered more severe than a one year prison sentence, and imprisonment is considered more severe than electronic monitoring. Yet, the relationship between the degree of liberty-restriction and the experienced severity is more complex. Based on ethnographic fieldwork in two Belgian and two Norwegian prisons, and phenomenological interviews with electronically monitored offenders, this article argues that a lesser degree of liberty-restriction can result in a more painful experience of this liberty restriction, but still contributes to the offenders' reintegration.
\end{abstract}

\section{Keywords}

Electric monitoring, freedom, imprisonment, liberty-restriction, subjective severity

\section{Introduction}

General statements regarding the severity of a particular sentence are often based on the degree of liberty-restriction of that sentence. This means not only that a prison sentence of five years is considered to be more severe than a prison sentence of one year, but also that imprisonment is generally considered to be more severe than electronic monitoring. Yet, research has shown that the relationship between the degree of liberty-restriction and the subjective experience of the severity of this sentence is more complex (Bronsteen et al., 2009; Sexton, 2015; Shammas, 2014; Vanhaelemeesch, 2015). Studying this complex relationship is particularly relevant given the growing importance of offenders' reintegration as an aim of punishment (Van Zyl Smit and Snacken, 2009). Indeed, the political and scholarly focus on reintegration has not only led to the awareness of unintended pains that may hamper a successful reintegration, but has also given rise to the question whether offenders' subjective experience of punishment should be taken into account in judicial decision-making (Bronsteen et al., 2009; Hayes, 2016; Kolber, 2009; Markel et al., 2011; Raaijmakers et al., 2014).

Two conceptual distinctions are fundamental to our understanding of the perceived severity of punishment in relation to the degree of liberty-restriction. First, the distinction between intended and unintended effects of the infliction of punishment. Understanding this distinction is crucial 
whether or not the unintended effects are considered part of the actual punishment (see e.g. Bronsteen et al., 2009; Markel et al., 2011; Van Ginneken and Hayes, 2017). Second, the painful effects of imprisonment should be distinguished from its harmful effects. By painful, we mean the negative experiences that are directly or indirectly caused by the prison sentence (such as physical pain, feelings of loneliness or frustrations about the loss of autonomy), while harmful effects refer to the (mostly unintended) negative consequences that last longer than the prison term itself (such as traumatization, broken relationships or loss of professional skills) and hamper a successful reintegration. Although there is a considerable overlap between those two categories, not all painful effects are harmful.

This article argues that the ongoing confrontation with freedom, which comes with a lesser degree of liberty-restriction, results in a more painful experience of this liberty deprivation. However, despite these additional unintended pains caused by the confrontation with freedom, it still contributes to the successful reintegration of offenders. Thus, we will argue that the deprivation of liberty in an open prison or in the context of electronic monitoring is often experienced as more painful than generally expected and less harmful than detention in a closed prison.

\section{The aims of punishment and its (un)intended pains}

Thinking about punishment and its severity does not happen in a vacuum. The desired severity of a sentence should be determined in relation to the aims pursued by this sentence and these aims are affected by the wider societal and penal context. Therefore, the questions 'Why Punish?' and 'How Much?', which Michael Tonry (2011) uses to attract our attention to his Reader on Punishment, sound very promising to every penologist looking for the answers about punishment. Yet, at the same time, it is clear that the answers do not exist. Given their embeddedness in the changing political and social context (O'Donnell, 2016), it is indeed not surprising that the questions as to 'why punish?' and 'how much?' continue to stimulate the debate on punishment.

The question 'why punish?' can be understood in two different ways. On the one hand, the question refers to the legitimate causes to punish: what actions or what behaviour should be punished and for what reasons - often referring to Locke's and Rousseau's social contract (Brettschneider, 2011; Draper, 2000). On the other hand, it refers to the aims of punishment, traditionally identified as retribution, general and specific deterrence, incapacitation, rehabilitation and reintegration (van Zyl Smit and Snacken, 2009). Without claiming to be exhaustive, we could add at least two other aims of punishment: restoration (Aertsen and Beyens, 2005) and expression (Garland, 2001; Pratt, 1995). The question 'how much?', then, refers to the desired severity of the punishment. In order to assess the severity of the punishment, two aspects should be considered: first, the nature of the punishment (e.g. 
deprivation of liberty) and second, the specific implementation of this punishment (e.g. detention in a particular prison for a fixed period of time).

Tonry (2011: 7) is right to argue that 'ways of thinking go in and out of fashion [...] but generally do not disappear'. Although this does not mean that thinking about punishment and penal practice is a mere reflection of the dominant societal views (King and Morgan, 1980), the answers to these questions have evolved significantly over time. Back in the 18th century, the first utilitarian thinkers like Cesare Beccaria and Jeremy Bentham thought about punishment and its aims in terms of the intended pains that should be produced in order to achieve the punishment aims. Beccaria, for example, answered the question 'why punish?' by making reference to his ideal societal objective: 'the greatest happiness shared among the greater number' (Beccaria, cited in Draper, 2000: 181). The pursuit of this happiness required the deterrence of citizens from committing crimes. This choice for deterrence as a suitable means to reduce future crimes was the logical consequence of his belief that human behaviour, including delinquent behaviour, could be explained by a reasonable cost-benefit analysis (Fijnaut, 2014). Consequently, answering the question as to how much the offender should be punished, Beccaria stated that efficient deterrence firstly requires that the nature of the punishment reflects the nature of the crime, and secondly that the severity of this punishment is in proportion to the severity of the crime. This means that the disadvantages of punishment should be slightly greater than the advantages of the crime (Fijnaut, 2014).

Inspired by the new insights of social, biological and psychological sciences, by the end of the 19th century, the main focus shifted from deterrence to incapacitation and rehabilitation. Delinquent behaviour was no longer considered the rational consequence of the offenders' costbenefit analysis, but rather the result of social, biological and psychological determinants (Fijnaut, 2014; Peters, 1996). Therefore, punishment was expected to address these determinants in order to prevent future crimes and to incapacitate dangerous offenders in order to protect society (Cullen and Gendreau, 2001). Together with this change in punishment aims, the question about the severity of the punishment was approached in a fundamentally new way. The duration of the deprivation of liberty was no longer expected to be proportional to the severity of the crime but was to be assessed in relation to the offenders' dangerousness or improvement - which led in some jurisdictions, like Washington or California, even to indeterminate sentencing (King and Morgan, 1980; Tonry, 2011).

As a result of the societal and scientific developments in the 1970s, trust in the rehabilitative capacity of prisons declined considerably (Daems, 2009; King and Morgan, 1980; Martinson, 1974), making way for an increased use of imprisonment as tool to manage and control crime (Bauwens, 2011; Feeley and Simon, 1992; Garland, 2001; Pratt et al., 2005). According to Ian O'Donnell (2016: 47), 'it could be argued that there has been shrinkage over time in the breadth of ambition associated with the expressed aims of imprisonment'. O'Donnell (2016) states that the aims of imprisonment are increasingly focused on the internal organization of the prison 
rather than on its social function, such as the reduction of future crime. Thus, he defines the aim of the imprisonment in a minimalist way: 'the aim of imprisonment is to reconstitute the prisoner's spatiotemporal world without causing avoidable collateral damage' (O'Donnell, 2016: 39).

Although O'Donnell (2016) admits that the official aims of imprisonment are in many countries more ambitious than the mere reconstitution of prisoners' 'spatiotemporal world', it is clear that the knowledge about the harmful effects of imprisonment has resulted in an increased focus on the reduction of these harmful effects rather than hoping for any positive effects. In the explanatory memorandum of the European Prison Rules of 1987, for example, the acceptance of less ambitious aims of imprisonment is explained as follows:

[T]he findings of evaluative research, that have demonstrated that penal treatments differ very little in their capacity to reform, have led to an emphasis on normalising life and activity within the prisons-the so-called 'reality prisons'. Proponents of that approach have held too that it can be important in diminishing the deleterious effects of imprisonment, that is, as yet, imperfectly understood and remains to be tested in pragmatic and objective terms. (Council of Europe, 1987: 82)

The shift towards reintegration as principal aim of imprisonment also implies the acceptance of the idea that the aims of the implementation of the prison sentence are relatively independent of the sentencing aims (van Zyl Smit and Snacken, 2009). This relative autonomy means that the sentencing aims can include retribution and deterrence, while the implementation of the prison sentence still aims at facilitating the reintegration 'at the level of the implementation of the sentence, the aim of retribution is fully fulfilled by the deprivation of liberty itself' (van Zyl Smit and Snacken, 2009: 81).

Although the deprivation of liberty is often spontaneously associated with the prison sentence, also the so-called 'community sanctions' imply a certain degree of liberty deprivation (Council of Europe, 1992). The official aims of these sanctions differ considerably across Europe (Snacken and McNeill, 2012). In some countries these sanctions were introduced with a view to resocialization, rehabilitation or even retribution, while in other countries community sanctions are meant to replace the punishment (McNeill, 2010, 2013). Despite these national differences, the European guidelines concerning probation, amongst which the EU Probation Framework Decision of 2008 and the Council of Europe Probation Rules of 2010, state that the main objectives are social rehabilitation and inclusion, public safety and the reduction of reoffending (Snacken and McNeill, 2012). Yet, the European Rules on Community Sanctions and Measures (Council of Europe, 1992: rule 6) suggest that the nature and duration of these sanctions should be determined 'in proportion to the seriousness of the offence', implying that 
community sanctions may indeed have a punitive character (Beyens et al., 1993; Van Kalmthout, 2000).

McNeill (2010) warns in this respect for a counterproductive shift in the aims of community sanctions (particularly in the English-speaking world), stating that rehabilitation is mainly considered a means for crime reduction and public protection rather than an end in itself. This is problematic for at least two reasons: first, community sanctions like probation cannot assure a complete prevention of risks and harm, and second, the work of probation services should not be limited to crime reduction but rather enable a 'constructive reparation by offenders enabling them to pay back for their crimes' (McNeill, 2010: 11). Despite this shift described by McNeill, community sanctions are still considered the less punitive alternative. In this context, Tom Daems (2013) discusses 22 functions of electronic monitoring, such as humanization, reintegration, harm reduction and enhancing offenders' responsibilities, and argues that these functions are always expressed in relation to imprisonment. Indeed, the offenders' reintegration only benefits from electronic monitoring when compared with imprisonment. The same is true for the reduction of harmful effects (Daems, 2013). Hence, Daems rightly wonders to what extent the potential harmful effects of electronic monitoring could be reduced.

\section{The perceived severity of punishment and the reduction of its harmful effects}

Insights into the limited positive impact of punishment have shed new light on the importance of offenders' individual experience with punishment and the reduction of harmful effects that can hamper offenders' reintegration. It is indeed not surprising that contemporary prison research is engaged with the unintended pains of punishment that should be limited rather than with the intended pains that should be produced in order to achieve the punishment aims. However, drawing a clear line between intended and unintended pains remains difficult (Hayes, 2016: 733-734).

Since Sykes' (1966) identification of five 'pains of imprisonment' - of which the deprivation of liberty was only one - this engagement has resulted in a whole series of pains of punishment, for example, pains of custody (Jones, 2007), spatial pains of imprisonment (Hancock and Jewkes, 2011), revisited pains of imprisonment (Crewe, 2011), paternal pains of imprisonment (Ugelvik, 2014), pains of probation (Durnescu, 2011) and pains of electronic monitoring (Payne et al., 2014).

One of the 'pains of electronic monitoring' identified by Payne and Gainey (1998) is the socalled 'watching others effect'. Offenders continue to see other people doing what they are not allowed to do themselves. In other words, they are living within society without being able to fully participate. Vanhaelemeesch (2015) points in this respect to what she calls 'the paradox of electronic monitoring'. While offenders are given the impression of being free, they still feel locked up. Because of this paradoxical feeling, some of her respondents experienced electronic 
monitoring as more punitive than imprisonment, and some of them, although the minority, even preferred imprisonment over electronic monitoring (Vanhaelemeesch, 2015).

In addition to this paradoxical feeling, electronic monitoring and detention in an open prison can create anxiety as well, especially for offenders coming from a closed prison. Shammas (2014) has described this anxiety as one of the 'pains of freedom'. In an open prison or under electronic monitoring, any mistake can have the dramatic consequence of being sent to a closed prison again. This is even more painful for offenders who are no longer used to take any responsibility for their own lives owing to their stay in a closed prison. Indeed, these offenders need a great amount of self-discipline (or self-regulation) to succeed (Beyens et al., 2007), all the more because living within society implies being confronted with all kinds of temptations (Vanhaelemeesch, 2015). Compared with imprisonment, electronic monitoring is a more civilized, invisible and sneaky way of punishing, forcing offenders to self-inhibition and to control of their own behaviour (Beyens et al., 2007).

Given these various pains of punishment, several authors have been addressing the question as to 'how much' offenders should be punished from a subjective perspective. Whereas advocates of 'standardised deprivation' (see e.g. Hayes, 2016) or 'objectivism' (Markel et al., 2011) consider the degree of liberty deprivation in purely objective terms, advocates of 'subjectivism' suggest to look at offenders' individual experience or perception as well (Bentham, 1982; Bronsteen et al., 2009; Kolber, 2009; Petersilia, 1990; Raaijmakers et al., 2014). Several studies have shown that offenders assess the relative severity of various sanctions in very different ways (Applegate et al., 2008; Crouch, 1993; May and Wood, 2005; Petersilia and Deschenes, 1994; Raaijmakers et al., 2014; van Ginneken and Hayes, 2017; Vanhaelemeesch et al., 2014; Williams et al., 2008).

Petersilia and Deschenes (1994), for example, found that intensive probation may become more dreaded than imprisonment, depending on the intensity and length of both sanctions. These findings confirm the results of Crouch's study (1993), which show that two-thirds of the respondents would choose one year in prison over 10 years on probation, and almost half of them would still opt for prison when the probation term is reduced to five years. In 2005, May and Wood (2005) came to the same conclusion, indicating that the presupposed continuum of sanctions with probation on the one extreme and imprisonment on the other, is questionable. In a follow-up research, Williams et al. (2008) asked over 600 probationers and parolees why they thought an offender might choose imprisonment over an alternative sanction. In their answers, the respondents referred to the avoidance of strict terms and supervision, and the will to get rid of the punishment as soon as possible. More recently, Raaijmakers and her colleagues (2014) found that their respondents' perception of the severity of a sentence was affected by individual variables like age, previous prison experiences and personality. This was already suggested by Bentham (1982), who referred to these individual variables as circumstances influencing sensibility. 
It has become clear that the perceived severity of punishment does not simply correspond to the degree of liberty-restriction. This does not necessarily mean, however, that the perceived severity should be taken into account in the judicial decision making process. Yet, this question has become more pressing since scholars have been linking the official aims of punishment to offenders' subjective experience (Applegate et al., 2008; Bronsteen et al., 2009; Erickson and Gibbs, 1979; Hayes, 2016; Kolber, 2009; Raaijmakers et al., 2014; Schinkel, 2014; Sexton, 2015; van Ginneken and Hayes, 2017). Applegate and colleagues (2008) even suggest that offenders' perceptions provide the fundament for the philosophies of punishment. It is clear, for example, that individual deterrence, and more specific the prevention of recidivism as a punishment goal is based on the (assumed) perception of the severity of the punishment. Indeed, a particular punishment can only deter potential offender when they perceive this punishment as severe enough (Applegate et al., 2008; Crouch, 1993; Erickson and Gibbs, 1979; Petersilia, 1990; Raaijmakers et al., 2014).

An important point of discussion in this respect is how to determine the proportionality between crime and punishment. The objective approach determines the proportionality between crime and the objective liberty deprivation, whereas the subjective - or 'intersubjective' as described by Hayes in his 2016 article on Penal Impact - approach will look at the proportionality between the crime and the pains experienced owing to the punishment. Yet another question in this respect is whether the unintended painful and harmful effects should also be taken into account when considering the proportionality between crime and subjective pains caused by punishment In their article on Happiness and Punishment, Bronsteen et al. (2009: 1038) argue that prisoners are able to adapt surprisingly well to their incarceration, which means that 'their happiness drops at the beginning and they expect it to remain at that low ebb, but it ascends as they adjust to their new surroundings'. This process of regaining a level of happiness that is more closely to their pre-incarceration level is called 'hedonic adaptation'. Adapting to the post-prison situation, which is often characterized by health problems, unemployment and broken relationships, on the other hand, appears to be much more difficult. Following this reasoning, imprisonment is less painful than expected, while the reintegration after imprisonment is more painful than one would expect.

For the purpose of their argument, however, Bronsteen et al. (2009) do not distinguish between painful and harmful effects, confusingly defining punishment as 'harm infliction', nor do they make a clear distinction between the intended and unintended pains. The absence of this conceptual distinction leads them to conclude that the harmful effects of imprisonment should be taken into account by the judge when determining the proportionality between crime and punishment. Refuting this argument, Markel et al. (2011: 618) use a more narrow definition of punishment that only includes the intended pains caused by the deprivation of liberty: 
'If the hardship endured by the offender is not authorized, intentionally imposed, and proximately caused by the state, then it is a conceptual error to call it 'punishment', even if it involves negative experience to the offender after his offense.'

Although this implies that the unintended and harmful effects of imprisonment should not affect the proportionality between crime and liberty deprivation, the authors do take these harmful effects seriously explaining that 'if the harms experienced are actionable constitutional torts, then they likely deserve some remedy, not because these harms are punishment but precisely because they are not' (Markel et al., 2011: 620, emphasis in original). This discussion illustrates the importance of the conceptual distinction between intended and unintended pains and between painful and harmful effects. Irrespective of whether or not the unintended (but wellknown) painful and harmful effects should be taken into account when imposing a sentence, understanding the individual experiences with punishment becomes increasingly important given their impact on offenders' reintegration.

\section{Method}

In the present analysis, we will focus on one particular pain of punishment: the ongoing confrontations with freedom whilst serving a liberty-restricting sentence. Shammas (2014) has already pointed out the specific pains experienced by prisoners in a Scandinavian minimum security prison: confusion; anxiety and boundlessness; ambiguity; relative deprivation and individual responsibility. These pains result from the particular character of the prison regime, involving more autonomy, more freedom of movement and more opportunities for prison leaves. Shammas (2014) refers to these pains as 'pains of freedom'. We will build on his findings in order to gain a deeper understanding of the complex relationship between the perceived severity of punishment and the degree of liberty deprivation.

More concretely, our analysis focuses on the way in which the ongoing confrontation with freedom affects the offenders' experience with three different liberty-restricting sentences: (1) detention in a closed prison; (2) detention in an open prison; and (3) electronic monitoring. This analysis is based on data collected in the context of our two different $\mathrm{PhD}$ projects. Yet, this painful confrontation with freedom was not explicitly addressed by either of the research questions, but rather spontaneously touched upon by the respondents of both studies. It struck us that we both came, independently from each other, to these unexpected results concerning offenders' experience with the confrontation with freedom, despite our different data collection methods and different research focus.

The first author conducted participant observations and interviews with prisoners in two Belgian and two Norwegian prisons. The observations consisted of 'being present' in each prison for a period of one to three months, while participating in daily activities (the level of 
participation depended on the characteristics of the prison) and seizing every opportunity for informal conversations with prisoners and staff (Gobo, 2008; Spradley, 2016). In addition, 25 prisoners were interviewed in a semi-structured way about their opinion on various aspects of prison life and the differences with the life outside prison. The interviews lasted between 20 minutes and two hours, and were recorded and transcribed verbatim.

The second author conducted phenomenological interviews concerning imprisonment and electronic monitoring. Using the descriptive phenomenological method (Giorgi, 1970, 2009), which is an in-depth methodology involving open interviews, the research aimed at exploring the lived experience of 'being punished'. As phenomenology is a philosophical approach, Giorgi translated the core ideas of phenomenologists Husserl and Merleau-Ponty into a methodology for human-scientific research. The interviews are based on open questions, asking about a specific experience. Additional questions can only be used to clarify what has been said, while the interviewer tries to maintain an open mind, free from hypotheses and presuppositions. The interviews focus on what was actually lived through, which means on the experience, not on attitudes or opinions. To be more specific, the four respondents of this study (seven interviews), who were all under electronic monitoring after being conditionally released from a closed prison, were asked about their experience of being punished and about the meaning of this punishment for them personally. During these interviews, the respondents elaborated on the consequences of the ongoing confrontation with freedom, which drew the researcher's attention to the unexpected complexity of this issue.

Although we are aware of the exploratory nature of our argument (given the small number of respondents and the fact that this topic was not directly addressed by the research questions of our studies), we believe that our analysis is strengthened by the fact that the respondents of both studies mentioned this painful confrontation with freedom regularly and spontaneously. We will illustrate our findings below with verbatim quotes from the respondents in both studies. However, the quotes that were originally in Dutch have been translated into English for the purpose of this article, which is indicated after the translated quotes.

\section{Findings}

We discuss the effects of the confrontation with freedom in the following three situations: first, in a closed prison in Belgium and Norway, then, in an open prison in Norway and, finally, with electronic monitoring as a condition for getting released from a closed prison in Belgium.

\section{Confrontation with freedom in a closed prison}

Imprisonment in a closed prison is the punishment with the greatest degree of liberty deprivation. Nevertheless, prisoners continue to be confronted with the outside world. The most direct confrontations with freedom in a closed prison are prison leaves and visits of family and 
other persons important to the prisoner. Receiving visitors was by many respondents experienced as paradoxical. Although these visits give prisoners the possibility to keep in touch with family and friends, and are often something to look forward to, they also confront prisoners more strongly with what they are missing. This confrontation with freedom, can therefore have the result that prisoners feel worse after the visit than they did before: 'I usually euh . . didn't want any visit. [.. .] Because the visits are hard, you know. The goodbyes are hard' (electronic monitoring [EM] after closed prison in Belgium). Moreover, the conversations during the visits make them realize more strongly what they are missing in terms of activities: 'Yes, after the visit you cannot go home together with your family, you know' (EM after closed prison in Belgium; translated from Dutch).

For these reasons, some prisoners try to make their prison time less painful by avoiding visits. Some respondents even explained their deliberate isolation from the outside world as a mental coping strategy:

'I must change in my brain everything to be easier [...] because it's too difficult if I'm here without my family ... friends and . . . . . . . I learned to live here in the prison. Yes, it's important to learn to live here ... [Researcher: And how do you learn it? Or, what do you learn?] I must [be] isolated from many things.' (Closed prison in Norway)

The same idea is expressed by another respondent, drawing attention to the emotional aspects associated with family: 'I know how to ... how to turn off the emotional side down here ... because I have a family outside, two sisters, a big family' (closed prison in Norway). Despite these painful experiences, visits are still necessary to maintain a social network and are often the most important thing to look forward to during the prison sentence: 'I have to get visitors because I would be crazy if I go one year without seeing my daughter. So . . I have to' (closed prison in Norway).

\section{Confrontation with freedom in an open prison}

The most defining difference between the closed prison and the open one is the lesser degree of liberty-restriction, reflected amongst other things by the absence of prison walls, the increased freedom of movement within the prison and the lower security level. Most respondents in the open prison compared their stay in this prison with their previous stay in a closed prison, explaining that the open character of the prison has the result that it is no longer possible to deliberately isolate oneself from the outside world:

'But in a closed prison your brain is just like turned off: you don't think, you don't do [...] I'm much closer to freedom [in the open prison], I don't have the 
same ability to close my mind, because I'm out doing things all the time.' (Open prison in Norway)

The unavoidable confrontations with freedom may lead to frustrations: 'You can see the cars pass but you can't drive it' (open prison in Norway), and make the deprivation of liberty, including the deprivation of the ability to participate in society, felt more strongly:

It is harder. Harder to be in open, because, you're thinking longer, you can see the life outside but you can't do it. When you are in a closed one, you are locked, you can close you in. You can close you in open prison, but it's not the same: you see the cars, you see people come. (Open prison in Norway)

Nevertheless, all respondents preferred staying in the open prison over a closed prison for at least two reasons. First, the fact that the liberty deprivation is more painful in an open prison, owing to the ongoing confrontations with freedom, does not mean that the punishment as a whole is considered to be more painful:

[I]n closed prison, I get very . . . I get very . . I get anxious, restless . . . Ja, because of other prisoners and guards and everything. It's . . it is much fighting and ... people steal, steal from each other and it's . . .. And you have people who, who wants to fight you. (Open prison in Norway)

Second, the respondents agreed that staying in an open prison has a positive impact on the reintegration. Whereas prisoners in a closed prison lose most of their responsibilities, prisoners in an open prison are expected to take responsibilities with regard to their reintegration, assisted by the prison staff:

If you're going to make the world after prison more manageable, you have to get some of the things around you in place, you know, like work, place to live, and get the transition as smooth as you can. So that's why open prison is the way to go. (Open prison in Norway)

\section{Confrontation with freedom whilst under electronic monitoring}

Electronic monitoring is the punishment with the lowest degree of liberty deprivation, when compared to detention in an open or a closed prison. Although most respondents still consider it as undeniable part of their punishment (after being conditionally released from prison), they appreciate the opportunity of being with their family again: 'I should be happy, but euhm, yeah, it's better than jail, I suppose' (EM after closed prison in Belgium). Moreover, electronic monitoring is generally considered as a good tool for reintegration, since the greater degree of liberty comes with a lot of responsibilities and commitments. For this reason, electronic monitoring causes a lot of stress too, not in the least because of the permanent threat of being sent back to prison: 
'I can't imagine anyone staying out, it's so hard, because you have to . . I don't know, I have to report everything I do to a . . . justice officer, to a parole officer' (EM after closed prison in Belgium).

Despite the lower degree of liberty deprivation (when compared with imprisonment), there are still numerous liberty restrictions, like the prohibition of going to certain places or associating with certain people, and the obligation to follow strict timetables:

'yes, it's still a punishment you know. Yes, it feels like a punishment ... Yeah, yeah, cause you are very limited in everything . . . uhm, you are very limited in coming and going as you want' (EM after closed prison in Belgium; translated from Dutch).

According to some respondents, these restrictions cause the paradoxical feeling of being free in theory but not actually feeling free: 'Yeah, yeah, much better, huh [than prison], no doubt, huh. But it's it's, yeah you're free and you're not free' (EM after closed prison in Belgium). The same feeling is expressed by another respondent:

'[Y]eah, I'm not free, I don't feel free. [Researcher: And are you glad you're free?] Yes and no, 'cause I don't feel free' (EM after closed prison in Belgium).

This is often experienced as a punitive aspect of electronic monitoring: 'And euh ... now I feel punished, because I'm free and I can't go see my family or nothing. That's . . . the biggest punishment of all' (EM after closed prison in Belgium).

Most respondents prefer electronic monitoring over staying in prison, and yet, some respondents consider electronic monitoring even more punitive than imprisonment:

Because the moment you go inside, ok, it's rough, after two or three years . . . it's all the same, every day is the same. I can do three years or seven years, there is no difference for someone who is inside. Because ... every day is the same and ... time flies ... and . . . yeah, that's it, so ... But when you get out, the rough times begin, really. (EM after closed prison in Belgium)

\section{The ambivalent effects of the ongoing confrontation with freedom}

Although we wish to underline the exploratory nature of these conclusions since they are based on a limited number of interviews, the findings discussed above contribute in two ways to our understanding of the relationship between the degree of liberty-restriction and the perceived severity of the liberty deprivation: a lesser degree of liberty deprivation seems to have more painful but less harmful effects.

As for the painful effects, it has become clear that the ongoing confrontations with freedom, which come with a lesser degree of liberty-restriction, have the result that offenders experience this deprivation of liberty more strongly. These findings are in line with Bronsteen et al.'s 
(2009) insights into hedonic adaptation in relation to the experience of imprisonment and with Sexton's (2015) understanding of the salience of punishment.

As described above, Bronsteen et al. (2009) explain that prisoners are able to adapt to their new surroundings, which has the result that the painful effects of the incarceration diminish after the initial entry shock. Central to the argument they make in their article on 'Happiness and Punishment' is the distinction between negative experiences to which people seem to adapt quite easily, such as prison life, and negative experiences that tend to resist adaptation, such as constant or worsening pain, but also post-prison life (Bronsteen et al., 2008, 2009). This distinction is explained by the different role of attention in these negative situations. Indeed, the adaptation is the result of a focus shift: 'because people tend to shift their attention away from the novel consequences of the event and back toward the mundane features of daily life' (Bronsteen et al., 2008: 1517).

Therefore, it could be argued that the confrontation with freedom makes it harder to adapt to the loss of liberty because the offender's focus is constantly drawn back to the deprivation. Whereas prisoners in a closed prison have the ability to focus on the life inside prison by isolating oneself completely and by 'doing their time' without thinking too much about the outside world, this isolation is no longer possible in an open prison or under electronic monitoring. Indeed, the confrontations with 'freedom' are a lot more prominent and inescapable there, which makes them feel their liberty deprivation more strongly.

Following Sexton's (2015) framework for penal consciousness, the painful confrontations with freedom can also be explained by prisoners' expectations of a sentence with a lesser degree of liberty deprivation. Sexton distinguishes two dimensions of punishment: severity and salience. Severity refers to the intensity or magnitude of punishment as it is experienced by the offender, while salience refers to the prominence of punishment in the offender's life (Sexton, 2015: 125, 128). Her understanding of the salience of punishment underlines the importance of offenders' expectations of the punishment: "salience of punishment is determined by the "punishment gap" between an individual's expectations and experiences of punishment' (Sexton, 2015: 114). This could explain why the deprivation of liberty in an open prison or in the context of electronic monitoring might play a more prominent role in offenders' life than generally expected.

The finding that the liberty deprivation in itself is more painful when this deprivation is less absolute does not mean, however, that the punishment as a whole is considered more painful. In addition to a high degree of liberty deprivation, imprisonment in a closed prison often involves a lot more unintended pains, which are rather indirectly related to the deprivation of liberty such as higher levels of violence and drugs, that still make the overall experience in a closed prison more painful.

In this sense, the experience of the liberty deprivation as such can be seen as one of the many aspects of the complete experience with liberty-restricting sentences. Although it is still difficult 
in practice to draw a clear line between the intended and unintended pains, the pains associated with the deprivation of liberty can be seen as the intended pains of the liberty-restricting sentence (see also van Ginneken and Hayes, 2017). A sentence with a higher degree of liberty restriction, like detention in a closed prison, is expected to be more painful than a sentence with a lower degree of liberty restriction, like detention in an open prison or electronic monitoring. In practice, however, the deprivation of liberty as such seems to be experienced as more painful when less intended pains were imposed.

As for the harmful effects, according to our respondents, these confrontations with freedom, do contribute to a successful reintegration of offenders afterwards. Therefore, we conclude that these unintended 'pains of punishment' are no harmful effects that should be avoided in order to facilitate the reintegration. On the contrary, the more prisoners isolate themselves completely from the outside world - for a considerable period of time - the more difficult the transition to the outside world will be. Indeed, all respondents agreed that detention in an open prison and electronic monitoring contribute to a better reintegration, even if it comes with those painful confrontations with freedom.

This brings us back to the questions as to why and how much offenders should be punished. If the implementation of a prison sentence and community sanctions truly aims at contributing to the reintegration of offenders, electronic monitoring and imprisonment in an open prison are preferred over imprisonment in a closed one. With regard to the question how much offenders should be punished, then, insights into the various intended and unintended pains are required, since punishment with a lower degree of liberty deprivation appears to be less 'soft' than often assumed by policy makers and public opinion (Vanhaelemeesch, 2015). Moreover, in view of the foregoing, the question arises again, and even more pressing, to what extent the subjective severity could or should be taken into account in the judicial decision-making process.

Although the principle of equality, understood as the same punishment for the same crime, provides a convincing argument to use objective criteria as basis for judicial decisions, the reverse is also true: in order to make sure that the inflicted pain is the same for every offender punished for the same crime, the subjective experience should be taken into account as well (Bentham, 1982; Raaijmakers et al., 2014; van Ginneken and Hayes, 2017). Rijpkema (2003, cited in Raaijmakers et al., 2014) refers to this distinction as formal equality versus material equality. Kolber (2009) argues that the material equality, or equal impact, should be taken into account when determining the 'just' punishment for a crime. In his opinion, it is even impossible to justify the punishment without considering the offenders' perception:

Any justification that ignores subjective experience [. . .] is incomplete and doomed to fail. The reason is simple: One should not purposefully or knowingly inflict substantial pain or distress on a person without some justification for doing so. . . . The reason we seek to justify punishment in the first place is to 
understand why we are permitted to subject offenders to the hard treatment of punishment. (Kolber, 2009: 197)

Although it remains open to debate which role subjective criteria should play in the judicial decision-making, the insights into the individual experiences of punishment become increasingly important in the light of the reintegration of offenders. Indeed, some painful aspects of the punishment may actually facilitate the reintegration while other painful experiences hamper a successful reintegration. But it is clear that unintended harmful effects should be proactively avoided, whether or not they are theoretically considered part of the punishment. Given the complexity of the relationship between the perceived severity of punishments on the one hand and punishment aims on the other hand, it is obvious that the questions 'why' and 'how much' will continue to stimulate debate on punishment.

\section{Acknowledgements}

We are grateful to Ivo Aertsen for his helpful comments on an earlier draft of this article, to the anonymous reviewers for their very constructive and helpful feedback, and to the respondents without whom these studies would not have been possible.

\section{Funding}

The author(s) disclosed receipt of the following financial support for the research, authorship, and/or publication of this article: This work was supported by the Research Foundation Flanders (FWO).

\section{References}

Aertsen I and Beyens K (2005) Restorative justice and the morality of law: A Reply to Brochu. In: Claes E, Foqué R and Peters T (eds) Punishment, Restorative Justice and the Morality of Law. Antwerp-Oxford: Intersentia, pp. 101-118.

Applegate BK, Smith HP, Sitren AH and Fariello Springer N (2008) From the inside: The meaning of probation to probationers. Criminal Justice Review 34(1): 80-95.

Bauwens A (2011) The Transformation of Offender Rehabilitation? Brussels: Vrije Universiteit Brussel.

Bentham J (1982) Of circumstances influencing sensibility. In: Burns JH and Hart HLA (eds) An Introduction to the Principles of Morals and Legislation. London-New York: Methuen, pp. $51-73$.

Beyens K, Bas R and Kaminski D (2007) Elektronisch toezicht in België: een schijnbaar penitentiair ontstoppingsmiddel. Panopticon 28(3): 21-40. 
Beyens K, Snacken S and Eliaerts C (1993) Barstende muren: overbevolkte gevangenissen: omvang, oorzaken en mogelijke oplossingen. Antwerp: Kluwer Rechtswetenschappen België; Gouda Quint.

Brettschneider C (2011) Rights within the social contract: Rousseau on punishment. In:Sarat A, Douglas L and Umphrey MM (eds) Law as Punishment - Law as Regulation. Stanford, CA: Stanford University Press, pp. 50-76.

Bronsteen J, Buccafusco C and Masur J (2008) Hedonic adaptation and the settlement of civil lawsuits. Columbia Law Review 108: 1516-1549.

Bronsteen J, Buccafusco C and Masur J (2009) Happiness and Punishment. The University of Chicago Law Review 76(3): 1037-1082.

Council of Europe (1987) Recommendation Rec(87)3 on the European Prison Rules (12 February 1987). Strasbourg: Council of Europe Publishing.

Council of Europe (1992) Recommendation Rec(92)16 on the European Rules on Community Sanctions and Measures. Strasbourg: Council of Europe Publishing.

Council of Europe (2006) European Prison Rules. Strasbourg: Council of Europe Publishing. Council of Europe (2010) Recommendation CM/Rec(2010)1 on the Council of Europe Probation Rules. Strasbourg: Council of Europe Publishing.

Crewe B (2011) Depth, weight, tightness: Revisiting the pains of imprisonment. Punishment \& Society-International Journal of Penology 13(5): 509-529.

Crouch BM (1993) Is incarceration really worse? Analysis of offenders' preferences for prison over probation. Justice Quarterly 10(1): 67-88.

Cullen FT and Gendreau P (2001) From nothing works to what works: Changing professional ideology in the 21st century. The Prison Journal 81(3): 313-338.

Daems T (2009) Bestraffingssociologie van David W. Garland. Den Haag: Boom Juridische uitgevers.

Daems T (2013) Functies en functionarissen van het elektronisch toezicht. In:Daems T, Vander Beken $\mathrm{T}$ and Vanhaelemeesch D (eds) De machines van Justitie: vijftien jaar elektronisch toezicht in België. Antwerp-Apeldoorn: Maklu, pp. 75-126.

Draper AJ (2000) Cesare Beccaria's influence on English discussions of punishment, 17641789. History of European Ideas 26(3-4): 177-199.

Durnescu I (2011) Pains of probation: Effective Practice and human rights. International Journal of Offender Therapy and Comparative Criminology 55(4): 530-545.

Erickson ML and Gibbs JP (1979) On the Perceived Severity of Legal Penalties. The Journal of Criminal Law and Criminology 70(1): 102-116. 
European Union (2008) Probation Framework Decision (2008/909/JHA).

Feeley M and Simon J (1992) The new penology: Notes on the emerging strategy of corrections and its implications. Criminology 30(4): 449-474.

Fijnaut F (2014) Criminologie en strafrechtsbedeling. Antwerpen-Cambridge: Intersentia.

Garland D (2001) The Culture of Control. Crime and Social Order in Contemporary Society. Oxford: Oxford University Press.

Giorgi A (1970) Psychology as a Human Science: A Phenomenologically Based Approach. New York: Harper \& Row Publishers.

Giorgi A (2009) The Descriptive Phenomenological Method in Psychology: A Modified Husserlian Approach. Pittsburgh, PA: Duquesne University Press.

Gobo G (2008) Doing Ethnography. London: SAGE.

Hancock P and Jewkes Y (2011) Architectures of incarceration: The spatial pains of imprisonment. Punishment \& Society 13(5), 611-629.

Hayes D (2016) Penal impact: Towards a more intersubjective measurement of penal severity. Oxford Journal of Legal Studies 36(4): 724-750.

Jones HL (2007) The pains of custody: How young men cope through the criminal justice system. $\mathrm{PhD}$ thesis, University of Hull, UK.

King RD and Morgan R (1980) The Future of the Prison System. Farnborough: Gower Publishing Co Ltd.

Kolber AJ (2009) The subjective experience of punishment. Columbia Law Review 109(1): $182-236$.

Martinson R (1974) What works? - Questions and answers about prison reform. National Affairs 35(Spring): 22-54.

Markel D, Flanders C and Gray D (2011) Beyond experience: Getting retributive justice right. California Law Review 99 (2): 605-628.

May DC and Wood PB (2005) What influences offenders' willingness to serve alternative sanctions? The Prison Journal 85(2): 145-167.

McNeill F (2010) Probation, credibility and justice. Probation Journal 58(1): 9-22.

McNeill F (2013) Community sanctions and European penology. In: Daems T, Snacken S and van Zyl Smit D (eds) European Penology. Oxford: Hart Publishing, pp. 171-192.

O’Donnell I (2016) The aims of imprisonment. In: Jewkes Y, Bennett J and Crewe B (eds) Handbook on Prisons. London: Routledge, pp. 39-54. 
Payne BK and Gainey RR (1998) A qualitative assessment of the pains experienced on electronic monitoring. International Journal of Offender Therapy and Comparative Criminology 42(2): 149-163.

Payne BK, Gainey RR and Wood PB (2014) The pains of electronic monitoring: a slap on the wrist or just as bad as prison? Criminal Justice Studies, 27(2): 133-148.

Peters T (1996) Probleemoplossing en herstel als functies van de straf. Panopticon 17(6): 555569.

Petersilia J (1990) When probation becomes more dreaded than prison. Federal Probation 54(1): 23-27.

Petersilia J and Deschenes EP (1994) What punishes? Inmates rank the severity of prison vs intermediate sanctions. Federal Probation 58(1): 3-8.

Pratt J (1995) Dangerousness, risk and technologies of power. Australian and New Zealand Journal of Criminology 28(1): 3-31.

Pratt J, Brown D, Brown M, Hallsworth S and Morrison W (eds) (2005) The New Punitiveness: Trends, Theories, Perspectives. Cullomptom: Willan Publishing.

Raaijmakers E, de Keijser J, Nieuwbeerta P, et al. (2014) De subjectieve zwaarte van detentie. Een empirisch onderzoek. Tijdschrift Voor Criminologie 56(1): 60-80.

Schinkel M (2014) Punishment as moral communication: The experiences of long-term prisoners. Punishment \& Society 16(5): 578-597.

Sexton L (2015) Penal subjectivities: Developing a theoretical framework for penal consciousness. Punishment \& Society 17(1): 114-136.

Shammas VL (2014) The pains of freedom: Assessing the ambiguity of Scandinavian penal exceptionalism on Norway's Prison Island. Punishment \& Society 16(1): 104-123.

Snacken S and McNeill F (2012) Chapter 2: Scientific recommendations. In: Flore D, Bolsy S, Honhon A and Maggio J (eds) Probation Measures and Alternative Sanctions in the European Union. Cambridge: Intersentia, pp. 561-571.

Spradley JP (2016) Participant Observation. Long Grove, IL: Waveland Press.

Sykes G (1966) The Society of Captives. New York: Atheneum.

Tonry M (2011) Why Punish? How Much? A Reader on Punishment. Oxford: Oxford University Press.

Ugelvik T (2014) Paternal pains of imprisonment: Incarcerated fathers, ethnic minority masculinity and resistance narratives. Punishment \& Society 16(2): 152-168. 
Vanhaelemeesch D, Vander Beken T and Vandevelde S (2014) Punishment at home: Offenders' experiences with electronic monitoring. European Journal of Criminology 11(3): 273-287.

van Ginneken E and Hayes D (2017) 'Just' punishment? Offenders' views on the meaning and severity of punishment. Criminology \& Criminal Justice 17(1): 62-78.

Vanhaelemeesch D (2015) De beleving van het elektronisch toezicht in vergelijking met de gevangenisstraf. Den Haag: Boom criminologie.

Van Kalmthout A (2000) Community sanctions and measures in Europe: A promising challenge or a disappointing utopia? In: Council of Europe (ed.) Crime and Criminal Justice in Europe. Strasbourg: Council of Europe Publishing, pp. 121-133.

van Zyl Smit D and Snacken S (2009) Principles of European Prison Law and Policy: Penology and Human Rights. Oxford: Oxford University Press.

Williams A, May DC and Wood PB (2008) The lesser of two evils? A Qualitative study of offenders' preferences for prison compared to alternatives. Journal of Offender Rehabilitation 46(3): 71-90. 